\title{
The continuity of indigenous rituals in African ecclesiology: A Kenyan experience from a historical perspective
}

\author{
Gathogo, Julius \\ University of South Africa \\ jgathogom@yahoo.com
}

\begin{abstract}
The article sets out to unveil the problem: Is there any effective continuity of indigenous rituals in African ecclesiology? In other words, has the faith of the church in African Christianity given room to some African rituals that are visible in the contemporary theo-doctrinal discourses? The article is theoretically informed by Samuel Kibicho's (1932-2011) supposition on 'radical continuity' in African religion into and through the Christian message. For him thus, this 'radical continuity' should be the starting point for African theology and African Christianity for that matter. In his view, African ecclesiology requires a 'radical reinterpretation' of the Christian concept of revelation, salvation, evangelization, Christ and religious rituals. While Kibicho approached African indigenous rituals from a theo-philosophical perspective, this article approaches the subject from an oral historical perspective. In its methodology, the article relies heavily on oral sources, interviews, and participant observation.
\end{abstract}

Key words

Indigenous rituals; African religion; ecclesiology; Samuel Kibicho; Kenya

\section{Introduction}

African Christianity in the $21^{\text {st }}$ century is characterized by conscious or unconscious continuity of African indigenous rituals that were prevalent in the African indigenous society; especially in the areas of baptism, catechism, and in the choice of worshipping centres. By surveying some case studies such as the Kithuthi site, along river Rundu of Kirinyaga County of Kenya, where initiation rituals were conducted in the indigenous society and where the Churches (mainly afro-Pentecostals) now conduct 
mass baptisms via immersion, the whole concept of 'continuity' is clearly seen. In this article, the continuity of African religious rituals in African ecclesiology is demonstrated especially through the sites where rainmaking rituals were conducted by Ethaga elders of the Irungu generation even though such sites were later taken over by the African church. In other words, after the sites were taken over by the church, ecclesiological rituals are now conducted in the same spots where indigenous rituals were previously done. Another indigenous conception that is evident in African ecclesiology is kuumithio concept, now gutaaro (instructions on maturity for teenagers) by selected elders.

Another ritual that resonates well with Samuel Kibicho's concept of continuity of African indigenous rituals to the African ecclesiology is the ceremony of rebirth for strangers in the community through slaughtering of a goat (Guciarwo na Mburi) which can be likened to the Christian rite of baptism. In my article on 'Missionaries and colonial authorities in Kenya', I have cited the case of one European missionary medical doctor, Dr. Crawford, who employed Pauline theological trajectory of becoming weak in order to win the weak and becoming 'all things to all men so that by all possible means I might save some (1 Corinthians 9:22). About Dr. Crawford and his understanding of continuity of African rituals in African ecclesiology, I have noted thus:

In particular, Crawford attempted to identify himself with traditional system of government; and in 1910, he sought to join the Embu Council of Elders with the hope of influencing the society from within. In addition, for his entrance fee, he presented the elders with a bull and there was a great feast. This made the Embu elders recognise him as one of their own, and his 'religion' as part of theirs. In turn, they promised him 'that they would now insist on all the people keeping God's Day and attending [church] service, and that he was to be the leading elder (Muthamaki). ${ }^{1}$

The article thus seeks to retrace the continuity of African indigenous discourses in the African ecclesiology in our contemporary society. Is the African ecclesiology beholden to African indigenous rituals? Is the success

1 Julius Gathogo, 'Missionaries and Colonial Authorities in Kenya', Swedish Missiological Themes, (2008) 96 (1), 43-70. 
of Christianity in Africa informed or enriched by indigenous resources as its raw materials? Is Kibicho's concept of 'radical continuity' of African religious aspects into African Christianity an overstatement or the reality on the ground?

In view of this, it is worthwhile to concede that African religion and Christianity have continued to interact in various ways since the arrival of the European missionaries in the early $19^{\text {th }}$ century. Through identity, lifestyles, arts, beliefs, practices, expression, and worldview, the said interaction and dialogue has continued throughout the history. ${ }^{2}$ The challenge has always been to determine the extent to which this interaction and/or dialogue has reached, hence the various theological trajectories such as Africanization, liberation, inculturation, adaptation, reconstruction and so on. Put it differently, how effective is the interaction between Christianity and African indigenous rituals? In this article, I have attempted to explore the various interactions, and/or dialogue points with specific case studies such as baptism and initiation, and instruction to adulthood among other sampled cases. The article has also revisited the religious factor in Kenya's war of independence as the so-called Mau-Mau rebels unconsciously attempted to demonstrate the continuity of African religion through, and sometimes without, Christianity.

In these interactions, African religion and Christianity, especially during the so-called European missionary era, always clashed in the environs of belief. The European missionaries dismissed African religion and its resultant rituals as paganism. ${ }^{3}$ Their belief in supernatural results was always dismissed as superstitious, fetish, animistic, crude, and uncivilized. The advent of Christianity, in East Africa, since the arrival of Rev. Dr. Ludwig Krapf in 1844 saw the discarding of the African beliefs; and a new religion appears to have entered into a new slate. As this article will demonstrate, this has not always been the case. The resilience of African religion has remained, as history will attest to this; for within the Christian faith continuity of African indigenous rituals remains manifest even in the $21^{\text {st }}$ century.

2 Julius Gathogo, Pangs of Birth in African Christianity (Saarbrucken: Lambert Academic Publishers, 2011).

3 Ibid. 


\section{The concept of radical continuity}

Samuel Gakuhi Kibicho (1932-2012), who came up with the concept of radical continuity in African religion as a pointer to its resilience, was a Presbyterian minister who became the first African Principal of St. Paul's United Theological College, now St. Paul's University. He later moved to the Department of Philosophy and Religious Studies in mid-1970s where he once chaired it, in the University of Nairobi. In his doctoral thesis, defended in 1972, and later published in 2006, as God and Revelation, Kibicho perceptively demonstrates that there is Radical continuity in African Religion even when it interacts with the Christian faith. This radical continuity is clearly demonstrated in the lives of Africans who convert to Christianity; and who necessarily find themselves practicing some of the African religious rituals. He however does not point out whether such rituals are consciously or unconsciously practised by the new convert to Christianity. In this book, God and Revelation, it comes out clearly that Kibicho was informed by Kenya's Mau-Mau war of liberation (1952-60) which was to an extent a religious conflict between African religion and its resultant rituals vis-à-vis other faiths and Westernization and its resultant cultures. In one of the songs, Hoyai ma amu Ngai no uria wa tene... That is, 'continue praying to God (Ngai) fellow comrades in the Kenyan war of independence, but remember that God is the same, the God of our ancestors.' In other words, the song was meant to remind the rankand-file of the African populace that even if there was a strong presence of Christianity that had come hand-in-hand with colonialism, with some having converted into it, they should never lose focus that there is continuity of worship, rather than a radical start of a new religion, as God has always been one for all humanity. Put it differently, there is no separate God for Europeans and Africans, for women and men, and/or for adults and children, and so on. It further sought to show that only new names such as Yahweh, El, Tzevaot or Sabaoth, Jah, Adoshem, Elohim, Elohai, El Shaddai, Eloah, Elah, Adonai, Hakadosh, Redeemer, Saviour, and Messiah, among others had changed with the coming of Christianity in Kikuyuland (read Africa). ${ }^{4}$

4 SG Kibicho, The Kikuyu Conception of God, (Unpublished PhD Thesis, Vanderbilt University, Tennessee, 1972). 
Clearly, as Kibicho has noted, there was no religion of Mau-Mau rebels; rather, there was the adaptation of various aspects of Kikuyu (African) traditional beliefs and practices, which led them to conduct binding oaths. The European missionaries in turn, saw this binding oath and African converts to Christianity, as mocking the Holy Eucharist. ${ }^{6}$ In an interview with Samuel Gakuo Macheru who was made to undertake the Mau-Mau oath, I gathered that this 'mockery' of the Christian rituals of the Holy Communion came out clearly, thus:

The oath consisted of the stomach contents of a slaughtered sheep or goat which were mixed with herbs, water and a little of the blood of the animal. The oath commissioner then placed a loop made of grass over the head of the initiate and over the hands of the initiate. The mixture described above was then placed in the hand of the initiate and a banana leaf containing the mixture was circulated round the head of the initiate seven times. The initiate repeated the oath as directed by the person conducting it. In this, the initiate would swear allegiance to the Mau-Mau [war of independence] course and that, he or she will uphold secrecy hence he or she will never betray the movement even if it results to death, give whatever is demanded of him, kill when necessary and generally be of help to the course of socio-political freedom. ${ }^{7}$

The Mau-Mau rebels also prayed and sacrificed to Ngai (God) before going to the various battles against the British government while facing Mount Kenya, which was the religious symbol for people living around it. As noted above, these rituals were accompanied by songs of worship to Ngai (God). ${ }^{8}$ According to LSB Leakey, a European missionary and a scholar who had invested heavily on the study of Kikuyu language and culture, Mau-Mau rebel movement 'was in fact [an African] religion and that it

5 Samuel Kibicho, God and Revelation. Nairobi: Acton.

6 Julius Gathogo, Mau-Mau Rebels in Kirinyaga County, Kenya (Saabrucken: Lambert Academic Publishers, 2016).

7 Interview with Samuel Gakuo Maceru, 31/01/2014, quoted in Julius Gathogo, Mau-Mau War and the Church in Kirinyaga, Kenya: Accounting for the Tension and Conflict (1952-1960), Studia Historiae Ecclesiasticae, December 2014, 40 (2): 21.

8 Julius Gathogo, Mau-Mau Rebels in Kirinyaga Count, Kenya . 
owed its successes to this fact more than to anything else at all. ${ }^{9}$ He goes on to say that 'it was this new religion, of which though oath ceremony formed only a small part that was the force which was turning thousands of peace loving Kikuyu into murderous fanatics. ${ }^{10}$ Leakey further says that militant Mau-Mau movement for Kenya's freedom was a 'very strange blend of pseudo-Christianity and utter paganism [the latter referring to African religion].' He suggested to the colonial government that the 'cure' for 'Mau-Mau disease' is to encourage the formation of African Independent Churches headed by a European missionary.

It was not in the oath alone that was an emphasis of the traditional Kikuyu religious elements. Traditional Kikuyu beliefs and practices were also emphasized in the Mau-Mau (the guerrilla fighters operating from Mount Kenya forest) conception of God, in their prayers, as well as in their other ceremonies. In view of this, Kibicho demonstrates the radical continuity of African religion when he stated, 'Mau-Mau held daily morning and evening prayers and made sacrifices to God under sacred trees in the traditional Kikuyu way. They faced Mount Kenya when they prayed, again according to Kikuyu tradition.' ${ }^{\text {11 }}$

Interestingly, Barnett and Njama, like Kibicho, saw the presence of African traditional rituals among the guerrilla fighters of Kenya's political independence (the Mau-Mau rebels) as 'continuities' of traditional Kikuyu religion into the present. He noted thus:

The magico-religious beliefs prevalent within the ranks of the guerrilla fighters, therefore, and the widespread acceptance of the legitimate military role and prophetic powers of the Mundu Mugo [Medicine Man] are best understood as continuities in traditional Kikuyu culture. ${ }^{12}$

9 LSB Leakey, Defeating Mau-Mau (London: Methuen, 1954), 41.

10 LSB Leakey, Defeating Mau-Mau (London: Methuen, 1954), 43

11 SG Kibicho, The Kikuyu Conception of God, (Unpublished PhD Thesis, Vanderbilt University, Tennessee, 1972), 273-274.

12 DL Barnett, \& K. Njama, Mau-Mau from Within: Autobiography and analysis of Kenya's Peasant Revolt (London: Monthly Review Press, 1966), 292. 
Nevertheless, Kibicho can be accused of lacking originality hence borrowing from Barnett and Njama who had written, before him, on the concept of 'continuity' even though his was 'radical continuity' and not just continuity. In particular, Kibicho discussed specifically the 'Radical Continuity of the Kikuyu Conception of God into and through Christianity' and not general continuity as such. ${ }^{13}$ Kibicho's idea of radical continuity received a strong endorsement from Elsie Mukami Kimathi, the revered rebel leader of the Mau-Mau Rebels during Kenya's war of independence, Dedan Kimathi wa Chiuri (1920-57) when she said thus:

The freedom fighters were highly religious people. They knew and prayed to the God of Gikuyu and Mumbi [the African God, Ngai]. They had their own Kikuyu commandments. Christianity did not bring any new conversion to the Kikuyu. Neither did it bring a new creed or a new code of ethics. The Kikuyu had their own. In addition, the freedom fighters followed the beliefs and commandments, which their ancestors had followed for long. ${ }^{14}$

It is interesting that Mukami Kimathi, the wife to the leader of the Kenya Land and African Army (KLFA) popularly called Mau-Mau movement, which was basically critical of westernization converted to Presbyterian Christianity in 1980s, though her husband, Field Marshall Dedan Kimathi Wachiuri, who was hanged on 18 February 1957 by the British colonial government in Kenya, after capture on 21 October 1956, was known as a practicing Roman Catholic adherent. Curiously, thus, though her husband was an adherent subscriber to the African religious rituals, he still kept strong ties with the Catholic Church where he was christened Dedan, even after capture in 1956. Through the various letters he wrote to his Catholic Cleric, his Roman Catholic faith stood out clearly. ${ }^{15}$ Could this have signalled how they (the rebel leader and his wife) viewed Christianity as a natural continuity from African religious rituals? Certainly, the Mau-Mau patriotic songs were mainly a corruption of the Christian hymns as sang in the missionary churches, and where African nationalist leaders such as Jomo Kenyatta (who later became the first president), Mbiyu Koinange, and

13 SG Kibicho, The Kikuyu Conception of God, 1972.

14 Julius Gathogo, Mau-Mau Rebels in Kirinyaga Count, Kenya, 38.

15 Julius Gathogo, Mau-Mau Rebels in Kirinyaga Count, Kenya. 
Harry Thuku among others replaced the names of the biblical patriarchs such as Abraham, Moses, David and Jesus Christ. In particular, one of the songs went as follows:

Ngai nieruhagia irikanirwo igatuika njeru kuri riua, Erire Iburahim na mugambo, niakaingiha ta Njata cia matui-ini ... (God renews covenants with the people. He told Abraham '...your descendants would increase like the stars... I will make you a great nation... I will bless those who bless you...')

Such a song, whose content is taken from Genesis 12:1-3, was revised and Kenyatta's name, rather than Abraham, was put instead. The danger is that the extremism of the rebels was not well grounded theologically; nor was there a clear theological position particularly due to poor educational standards of the rebels. In fact, most of them were illiterates or semiilliterates; and who joined the bandwagon of the quest for land and freedom as a religious duty to the nation.

Similarly, the erstwhile Mau-Mau oath administrator during the mid-1940s and 1950s, Muchunu Gachuki, echoed Elsie Mukami Kimathi's sentiment on the continuity of African religion in Mau-Mau rebel activities. Though he was a member of African Independent Pentecostal Church of Africa (AIPCA), Gachuki noted, thus:

Religion consists of vows and commandments. People who have no sacred vows cannot be said to be religious. The Mau-Mau had vows and commandments just like the Christians have their 'creeds'. Our 'creeds' in Mau-Mau were organized in accordance with those of Kikuyu Central Association [political party formed in 1925] which existed before MauMau. The 'creeds' used in Kikuyu Central Association [KCA] were in turn based mainly on the traditional beliefs of the Kikuyu. As such, the MauMau did not create any beliefs. They relied on those were in existence among the Kikuyu for many years. Those beliefs and commandments comprised a great deal of our religion in the [fight for freedom] movement. We also had prayers in which we continuously emphasized the unforgettable and bitter fact that, 'we are praying to the God of Gikuyu and Mumbi' who gave to us this country - a country that was alienated by the Europeans. ${ }^{16}$

16 Muchunu Gachuki quoted in Julius Gathogo, Mau-Mau Rebels in Kirinyaga County, Kenya. 
Having seen how Kibicho's concept of radical continuity manifested itself in the socio-political scene in colonial Kenya, it is critical that we also consider the ecclesiastical scene. Indeed, there are several elements within both the Catholic and the Protestant wings of the church that appear to attest to this position. To that end, a few case studies have been cited.

\section{A case of the Catholic Church, Kagumo Town}

First, the Catholic Church of Kagumo (hereafter, CCM Kagumo) in Kirinyaga County of Kenya begun in 1956; and was situated in the area that is currently occupied by the Full Gospel Churches of Kenya, Kagumo Town (hereafter, FGCK-Kagumo). From there, the members built another church in 1960s in the place where a local prominent businessperson, Phillip Mwangi Gaite, has put up his 'PM Gaite Trading Company Limited'. They however continued occupying the place where FGCK-Kagumo is located by virtue of the fact that even though their main activities were relocated, their catechism classes remained in the same spot. The second building was put up in the 1970s in the place where the Kagumo Life Giving Centre (Dispensary) is situated. ${ }^{17}$ Again, after the successful construction of the second church, the worshippers continued to undertake catechism classes in the old church. The inability to drastically shift from the previous church points to the nature of religious discourses where paradigms don't necessarily shift radically, but maintain some elements of continuity; hence maintaining harmony with the former.

The construction of the third church building, which is the concern of this section, begun in mid-1970s, which is about 15 years after Kenya's political independence (1963-1970). Characteristically, as the reality of the political independence sank in the national psyche, the old rhetoric of blaming everything on the missionaries and the colonial government begun to die out gradually. The young nation, with the new African leadership, was struggling to fix an assortment of socio-ecclesial issues, hence it was now easy to fathom the new religious reality, where people, especially in Central Kenya, begun to replace the local nine clans, as the main centres of socializing and communal development, with churches. In fact, since the coming of the European missionaries, schools in Central Kenya, and in

17 Interview with church elder, Joseph Karimi Karuri, 13.04.2016. 
most parts of the country, belonged to the Church. ${ }^{18}$ In turn, these schools promoted the various denominations that had taken the various spheres of influence; hence the post independent Kenya saw the emergence of Churches, particularly the missionary societies turned Churches (refer to Anglicans, Methodist, Catholic, Presbyterian etc.), emerge as a centre of socio-economic power.

The building of the third Roman Catholic Church in Kagumo Town, in the1970s, can thus be understood from that background, a background of self-realization among the citizens of the young nation that they have their country to build; and to an extent, they have Christianity and the church as their reality to take care of. Curiously, the third and indeed the present church, CCM Kagumo occupies the land that was not allocated to anybody during the 1957 land demarcations. ${ }^{19}$ Why? According to the leading church elder, the adherents of African religion considered Joseph Karimi Karuri, the land a Holy Land or a Sacred Ground; hence, the colonial government, in its 1957 Land Demarcation, did not tamper with such revered places, across the vast lands of Central Kenya. ${ }^{20}$ In particular, the area occupied by CCM Kagumo was the land where the Ethaga rainmakers of the Irungu generation conducted their religious discourses. As it turned out, the reality of the new religio-social dispensation made the Irungu elders, the priests in African religion, to voluntarily give out their worshipping site to the church through the custodianship of the then County Council of Kirinyaga, now the County Government. ${ }^{21}$ Certainly, the Ethaga elders of the Irungu generation had several worshipping Shrines (Ithaka na Nyumba). In the case of the Shrine that now hosts CCM Kagumo, it belonged to the Irungu elders of Kabari sub-location. At Kamuiru Shrine where we now have a County Dispensary, the Irungu Shrine therein served the people of Kirunda sub-location. As noted earlier, it reached a time when the Irungu elders began to give out some of their Shrines to the Churches.

In the 1970s and 1980s, as the Irungu cultural and religious elders were surrendering their revered worshipping centres to the churches through

18 Interview with Aram Murage Hezekiah, 13.04.2016.

19 Interview with Joseph Karimi Karuri, 13.04.2016.

20 Interview with Joseph Karimi Karuri, 13.04.2016.

21 Interview with Joseph Karimi Karuri, 13.04.2016. 
the local government, as the law dictated, the person within Kirinyaga County Council who was administratively responsible for this hand-over processes was one, Mr. James Njogu Mabu, later Anglican Lay Canon James Njogu Mabu. ${ }^{22}$ As the Administrator of Kirinyaga County Council, Canon Mabu was the first to be requested by the Ethaga elders to take the Holy Shrine on behalf of his Anglican Church, which he readily accepted before he understood their conditions that eventually drove him out of the deal. Briefly, they told wa Mabu, as he was popularly called, to provide the ritualistic ram without blemish and two crates of beer (Itumbi cia Njohi). As a leading and devoted member of the East African Revival Movement that began in Rwanda in 1927, closed over to Kenya via Uganda in 1937, wa Mabu's pietistic stand could not allow him to entertain such 'un-Godly' practices. He therefore told them that his faith could not allow him to sell, touch or prescribe to anybody things that are harmful to our bodies, which are the biblical Temples of God (referring to 1 Cor 6:9).

Without biblical exegesis, wa Mabu like other revivalists whose theological standpoint was beginning to dominate the leadership of the mainline protestant churches, dismissed the beer and African traditional practices as overtaken by Christ's salvation hence culture and indigenous rituals, in his view did not have a place before Christ. Considering that the movement is one of the few revival movement founded by a European missionary (Dr Joe Church) and an African from Uganda (Simeoni Nsibambi) after both undertook serious bible study on the Holy Spirit. ${ }^{23}$ Subsequently, they both felt called to lead the people of East Africa to Christ's salvation. It is from there that they vigorously led in revival crusades across East Africa, indeed, it was a kind of an interdenominational church and/or an independent church within the mainline Protestant churches (Anglicans, Presbyterians, Lutherans, Reformed, and Methodists) - even though members did not defect from their respective Churches.

Thus, because of the study, Joe Church and Simeoni Nsibambi sank into deep spiritual experience. The experience became the driving force that led

22 Interview with Eliud Gicuki Gathumbi, 03.02.2016.

23 Kevin Ward, 'A History of Christianity in Uganda.' In Zablon Nthamburi, (ed.) From Mission to Church: A Handbook of Christianity in East Africa (Nairobi: Uzima, 1995), 103. 
to a series of conventions, which include the Gahini convention of 1933, the Kabale Convention of 1935, the Mbarara Convention of 1936 among others. While the three noted conventions took place in Rwanda (Gahini) and Uganda (Kabale and Mbarara), the revival had reached Maseno of Western Kenya in as early as 1937. It is in Uganda where the adherents were renamed Balokole (saved ones). From its [Rwandan] origin thus, it spread its wings to the rest of East African countries fast, even though it was too legalistic. It forbade beer drinking, smoking, taking snuff, and clitoridectomy (female genital mutilation) or 'circumcision' of girls. It also forbade social relationships between girls and boys; and indeed all unmarried persons must constantly confess not only their personal encounters with Christ in as many times as possible, but also more importantly their marital faithfulness. ${ }^{24}$ It was the responsibility of elders in the movement to arrange marriages for its young members. This implies that the Christian revivalists did not see the value of courtship among the youth, as the elder's prayer was enough resource in marital matters. Any member who went against this code was ex-communicated. Despite having a very legalistic stance, it changed the socio-ecclesial landscape of the East African region to date.

In the case of James Njogu Mabu who was a leader of both sides of the socio-ecclesial divides, the request to adhere to the African religious rituals, where he had already been 'saved from' was a painful drug to gulp. Unable to subscribe to the Canons of African religious heritage, he turned down the offer to take the Irungu Shrine to his Anglican Church; even though the Anglican Church was badly looking for a mere plot of land to build another Pastoral Centre - owing to the huge popularities in Kagumo Town and its surroundings. As a good catchment area, every church was looking for a plot of land; hence, such an opportunity could not be turned down easily. Wa Mabu however had the guts to turn the offer down as it contradicted his revival faith. It's from there that when the former Member of Parliament (1963-1969) for the larger Ndia Constituency (later divided in 1996 into Kirinyaga Central and Ndia Constituencies), Hon James Njagi Kibuga, Eliud Wambu wa Mugo, and the Rev. Father Clipper Romerio

24 Kevin Ward, 'A History of Christianity in Uganda' In Zablon Nthamburi, ed. From Mission to Church: A Handbook of Christianity in East Africa (Nairobi: Uzima, 1995), 103. 
(an Italian Priest serving there then) heard this ritualistic contestations, they rushed to the Irungu indigenous ritualists and subsequently agreed to honour all their terms. In a fraction of a week, the Ram and the two crates of Beer were brought and every other detail was followed to the letter, as requested by the elders. ${ }^{25}$ After the indigenous leaders ate the roasted meat within the Shrines, and some beer poured down to appease the African ancestors, the handover of the Holy Shrine was complete. The rest was to follow up the administrative procedures within the offices of the local county government. Ironically, it is the same Lay Canon Njogu wa Mabu who oversaw those processes until the CCM Kagumo got all the legal details that allowed them to own the land that they occupy to date. ${ }^{26}$ Hence, by 1975, CCM Kagumo had the land while the Anglicans led by wa Mabu kept the revival faith. In turn, the Irungu elders who participated in the handover ceremony of giving out the Kagumo Shrine were Gitoro wa Gakura, Gikaracu, Kinui among others. ${ }^{27}$ It is from there that Father Clipper led in the clearing of bushes and the construction of the Roman Catholic Church until it was completed.

Perhaps, it is imperative to ask: Why did the elders choose to give out the revered ritualistic shrines to the church? As noted, the new religio-social trajectory in postcolonial Kenya was bending towards the church as the emerging centre of religious-social growth. In paraphrasing the Rev Dr Martin Luther King Jr (1929-68) in his commonly quoted statement on the 'arc of the moral universe' as long and as bending towards justice, the arc of the peoples religious consciousness, especially when it failed to rain, was to go on their knees in their respective Churches, and indeed dedicate a day of prayer on this; rather than rely on the Ethaga indigenous ritualists who would slaughter a sheep or a ram without blemish and sacrifice it to God with huge heaps of firewood. As the huge smoke came out, it would bend towards the local Mount Kenya, a revered mountain of God, and it was believed that God would hear and send heavy rains. Considering that schools belonged to the Churches, a new team of worshippers of the new 'religion' had been 'prepared' long enough to an extent that the die for

25 Interview with Eliud Gicuki Gathumbi, 03.02.2016.

26 Interview with Eliud Gicuki Gathumbi, 03.02.2016.

27 Interview with Joseph Karimi Karuri, 13.04.2016. 
some indigenous rituals was arguably cast. As they continued to compete with the 'new' religion, the 1970s and 1980s was definitely bad for them. Or was had the continuity of African rituals, in 1970s and 80s, reached another level that now needed it done in churches rather than shrines? Interestingly, there are some cases when African rituals are conducted in the shrines even in the $21^{\text {st }}$ century, especially when there is a national crisis, war, serious misfortunes, drought and so on. The church however remains the ritualistic norm for the society. Nevertheless, the elders had to probably 'continue' in disguised ways, hence the giving up of the Shrines across the region to their 'competitors'.

Another probable reason that made Irungu elders to give out their shrines is that they realized that, as the kikuyu proverb says, wathi wakura wongagirirwo ungi (that is, once an idea develops, it leads to yet another better idea, and/or an idea always develops a newer continuing idea for the better). It can also mean, a good idea gives room to yet a new and/or better idea. Certainly, Irungu elders, as a priestly class, foresaw a situation where they were no longer able to recruit their successors as they advanced in age. In the 1970s, the youths were more interested in the new faith, which was less involving - the Christian faith. In other words, they could see how the moral fabric of the society had gone down. Hence African religion had been desecrated too much to be entrusted to the emerging generation (kuthatia ndini ya mundu muiru). The damage could not be repaired easily as schools had been used to discredit it; indeed, it had been downplayed through the western syllabuses that the marked the imprints of the Western missionaries. This does not however mean the death of African religion; rather its continuity through the medium of the church and through other areas such as in marriage, birth, initiations, harvesting, political, and burial ceremonies among others.

A significant observation is that the entrance door of the present day CCM Kagumo is placed in the very same 'Gate' that the Irungu elders used as they went to conduct their religious rituals. Further, the post that holds the altar is the same one that Irungu ritualists used to conduct their discourses. This ancient post, used as the altar, was only modified by being wrapped by a mass-designed cover. Indeed, this flat-topped block used as the focus for a religious ritual, and especially for making sacrifices or offerings to God, remains the way it was as the elders handed the shrine to the church 
in 1970s. Is this a deliberate or an unconscious effort that demonstrates the continuity of African religion through African Christianity?

Undoubtedly, the importance of the altar is clearly laid out even with the Abrahamic religions such as the Judaism and Christianity. In particular, Abraham built four main altars for God. The first one was an altar in the midst of his enemies (Genesis 12:5-7), and the altar of intimacy as he came to know God as more than just the God of all creation and power. Hence, he was finding a more intimate familiarity with God (Gen 12:8). The third altar that Abraham built was the altar of no return (Gen 13:3-4). This was after his trip to Egypt that was indeed a sad commentary on his fear and weakness. He built an altar of restoration to his former commitment; and it is where he put down a stake saying, 'I am here where God means for me to be, and there will be no wondering again ever!' (Genesis 13:4). The fourth altar that Abraham built was the altar of possession (Genesis 13:17-18). It was an altar of not just promise but of possession and fulfilment. Hence, in both the Ethaga elders and the biblical understanding, altars were forms of covenant between humanity and God.

From an eyewitness, as the Irungu elders handed over the shrine to CCM Kagumo, they sang a ritualistic song, 'Weru-uyu ni wao-i? Ni wa Irungu na Mwangi-I, Kiama mukari-ira o rumandi', that is, 'Whose shrine does this one belong to? It belongs to both Irungu and Mwangi generations. Elders, you will one day eat together. ${ }^{28}$ Were they prophesying a day when both generations will eat together, as they enter into a new religio-ritual paradigm (new religion), which appreciates both Jew and gentile?

Another recurrent feature in both the Ethaga rituals and Christian rituals in CCM Kagumo is the giving of tithes and other offerings. As in the times of the Ethaga elders, offerings are still taken to the very place where it was taken then, and which is where Mary's icon is placed within the church compound. Ethaga elders used to call the place, Ikumbi ria matega or the Granary of the Offerings. After seasonal harvests, women would put some of their products such as maize, peas, millet, sorghum and other farm produce in the same place. The Irungu ritualists would later feed on these items just as priests in our Churches receive such offerings. In the case of

28 Interview with John Kinyua Mwangi Gatimu, Kagumo Town home, 13.04.2016. 
Ethaga elders, the food would be cooked in another spot by elderly women (past menopause) and served to Irungu ritualists. In a nutshell, Mary's grotto is the place where the Catholics go for prayer. It is also in the place where the offerings (Matega) were put as a form of worship. Curiously, as the constructor built Mary's grotto in CCM Kagumo, he did not know that it was the same place where the offerings (Matega) were taken when the compound was a Shrine. ${ }^{29}$

Just as in the era of Ethaga-Irungu ritualists, a worshipper takes his or her offerings willingly, as his or her covenant with God; and this remains a personal matter. Similarly, in both cases, there are prescriptions and/or prohibitions - as a measure of maintaining the sanctity of the place of worship. In the case of it as a Shrine, one was not allowed to go to the toilet there; or fetch firewood, or make unnecessary noise there, or shepherd. Further, a non-Irungu elder was also not allowed to enter there and defile the Holy Ground. Such prohibitions are in tandem with the Decalogue where the Hebrew were given the Ten Commandments (Ex 20:1-17).

Concerning the Day of Rituals, the locals were not allowed to go to work, and/or to farm. It was called, Muthenya wa Mutiro (the Day of Abstaining). It was also called the Day of the Goat or the Day of the Sheep (Muthenya wa Mburi or Muthenya wa Ng'ondu). Interestingly people who were served by a different Shrine apart from the area surrounding the present day CCM Kagumo were not affected by the prescriptions of the Day and vice versa. For example, while the people of Kabari sub-location could not carry out normal duties when Irungu ritualists were sacrificing to God (Ngai), the neighbouring Kirunda sub-location who were served by the Kamuiru Shrine would go about their daily discourses as usual.

Concerning the mode of communicating to the general society that the Day of Abstaining had reached, the Irungu elders would go to the various routes/roads and/or paths as they put Ithare tree branches to remind the people about the Day of Sacrifice and the observances expected of them. If one saw Ithare tree branch planted along the roads, he or she would return to the house or home for that matter. ${ }^{30}$ This compares with Sunday - the Christian day of worship for most denominations. Regarding how

29 Interview with Joseph Karimi Karuri, 13.04.2016.

30 Interview with Aram Murage Hezekiah, Kagumo Town home, 13.04.2016. 
one became a ritualist, it involved, in some cases, parentage where one inherited from parents, in other cases, religious specialists trained one just as priests train through theological institutions - hence some elements of continuity are visible. Nevertheless, rituals that collated one into a group were heavily guarded. Regarding the actual spot where sacrifices were conducted, they would look and see how and where the smoke was moving. Was it straight, upright? This compares with the election of Popes - as the Cardinals observe how the ritual smoke progresses.

On a visit to the ritualistic shrine turned CCM Kagumo on 13 April 2016, the researcher and his assistants were impressed to read the plaque on the church wall thus: 'This foundation stone was blessed by The Rev Father Pietro Baudena, Regional Superior of Consolata Fathers and laid down by Hon James Njiru, Assistant Minister for Health, on 5 January 1975. The church was consecrated by the Rt. Rev C. M. Gatimu, D.D. and opened by Hon. James Osogo, Minister for Health on 2 November 1975.' The other plaque on the church wall reads, 'Kagumo Catholic Parish was inaugurated by Bishop Peter Kairo of Catholic Diocese of Murang'a on 16 January 1994.' Clearly, these plaques implies that the continuity of indigenous rituals have moved a full circle into and through African ecclesiology, as the ritualistic Shrines are fully absorbed in the society in their new status.

\section{Continuity from initiation rituals through to baptism?}

Another critical element that is evident in African ecclesiology is the third African rite of passage, circumcision. There were specific places where initiates were taken for kuunithio (advice and instructions to adulthood) before the rite of circumcision took place. Such an Elder who counselled a prospective initiate was called Mutiri Mugi (the Wise Guardian). Some 'Wise Guardians' (Atiiri, plural for Mutiri) would reject the offer if called upon, just as the Christian god-parents can reject a request to present a person from particular homes or families to the baptizing or confirming cleric. If a family had 'hardcore' characters who would later embarrass the Mutiiri (wise guardian) with bad behaviours, then declining the offer could be understood along those lines. Nevertheless, a Mutiiri was a highly respected person; and who counselled on matters such as marital challenges, gave caution on witchcraft, inter-clan wars, stealing and eventually sought to impart virtues in a person, just as the Christian catechists do. As the 
mainline churches set up counselling sessions after class eight level of education, after which girl-children are sent home as boys are left for a second week to heal after circumcision, the continuity of indigenous rituals in African ecclesiology can be experienced in this way. Some of the places where boys and girls who have completed primary school education are called during December holidays for a week for girls (who are no longer circumcised as in the past) and two weeks for a boy-child include: Mutira Girls Secondary School of Kirinyaga County (Anglican church initiative), Wogget Centre in Mombasa County (Presbyterian Church initiative), and St. Thomas Anglican Cathedral, Kerugoya (Kirinyaga County) among other centres belonging to various denominations. In this way, church counsellors have replaced the place of Mutiiri (wise guardian) who counselled boys and girls before initiation.

After the traditional counselling, prospective initiates were taken to the various bathing centres, though young men and women were counselled by people from their respective sexes; and eventually taken early in the morning (mainly men), around $4 \mathrm{am}$, for the cold ritual bathing. The reason for the cold morning bathing was to reduce pain. Again, the specific spots that were earmarked for ritual bathing were indeed revered places, and/or sacred places. In Kirinyaga county of Kenya, they include Kithuthi near Kagumo Town along River Rundu (also called River Ruthu), Kiaritha near Kerugoya Town and along River Rutui among other places. In the places where traditional counselling was done before initiation near River Rutui, Rev. John Kangangi explained to the researcher that it is 200 metres from the present day St. James Kiaritha Anglican Church. ${ }^{31}$ In these ritual centres such as Kithuthi, Mucagara along River Kamweti, Kamacia-Matiru along River Nyamindi, Kiaritha along River Rutui, Riakiania along River Rwamuthambi, Weru wa Nguuru along River Thiba and Embu along River Rupingazi, and Meru along River Thuci where ritual bathing before circumcision was conducted, Afro-Pentecostal Churches took over and converted the sites into their worship centres, and where baptismal services through immersion are done. ${ }^{32}$ Afro-Pentecostal Churches that have

31 Interview with Rev John Kangangi Mithamo, CCS Kerugoya hotel, 12.04.2016.

32 Interview with Joseph Kariuki Gatimu, Aberdare Annex Hotel, Mombasa, OffNkrumah Road, 12.07.16. 
taken over the old ritual bathing places include Pentecostal Evangelistic Fellowship of Africa (PEFA), Full Gospel Churches of Kenya (FGCK), Christian Church International, Redeemed Churches, Jesus Victory Temple, and Gospel Outreach among others.

\section{Theological and ecclesial continuity}

In Jesse Mugambi's view, Jesus demonstrated radical continuity in wanting to go to the Jewish roots despite being truly God and truly man..$^{33}$ This is clear when he reasoned with Jews (Jn 8:39). He also accepted the baptism of John the Baptist, who was his forerunner (Matthew 3:13-17). As a thump stamp for cultural continuity, Jesus cautioned, thus, 'Do not think that I have come to abolish the Law or the Prophets; I have not come to abolish them, but to fulfil them' (Matthew 5:17).

In operating within the same cultural continuity, Jesus was dedicated to the Temple when he was forty days old according to the Law of Moses (Lk 2:22-40). Considering that Joseph and Mary were Jews, and followed the customs of their nation, the dedication in the Temple at Jerusalem marked the fulfilment of the prophecy of Malachi (3:1b-), that 'suddenly, the Lord you are seeking will come to his temple, the messenger of the covenant, whom you desire, will come.' Similarly, St. Paul reasoned in the synagogue in every Sabbath when he was in Corinth. In this, he tried to persuade Jews and Greeks alike (Acts 18:4). Such pointers demonstrate that the continuity of African indigenous rituals into and through African ecclesiology, as cited above is in continuum with theological continuity; and not an isolated Theo-historical development.

It is interesting that Jesse Mugambi, in echoing Kibicho (1972) saw the Africans who gave plots of land for the construction of churches as radical continuity of indigenous discourses into and through African ecclesiology. ${ }^{34}$ Certainly, Kibicho's view of radical continuity is in tandem with the Donatist controversy, in North Africa, which flourished in the fourth and fifth centuries. In turn, the Donatists (named for the Berber Christian bishop Donatus Magnus) were members of an offshoot church

33 Interview with Prof Jesse Mugambi, 18.09.2016 in his Nairobi West home.

34 Interview with Prof Jesse Mugambi, 18.09.2016 in his Nairobi West home. 
that did not follow the same doctrine as some other churches of the rest of Early Christianity in late antiquity. ${ }^{35}$ Donatism had its roots in the social pressures among the long-established Christian community of Roman North Africa (the present day Berber countries - Algeria and Tunisia), during the persecution of Christians under Diocletian. ${ }^{36}$ Put it differently, Donatists were traditionalists who wanted the tradition of Berbers in North Africa be taken seriously. Since they were operating within the Roman Empire, Latin language was the official language that the Donatists detested. When the Roman Emperor intervened, the Donatists were crushed marking the death of Christianity in North A frica. In other words, the Latin interference made Christianity die. To put it differently, the failure to allow Berber rituals and language to thrive within Christianity means ritual continuity was suppressed and Latin, the language of the then minority, was given prominence over that of the Berbers who were all subjects of the Roman Empire. Certainly, the Roman Empire that favoured the colonies that were Latin speaking, worked conspiring with the church. In addition, even though they formed a minority, Latin speakers in North Africa were favoured. In the postcolonial reconstructive phase, the resurgent of traditionalism is arguably because there is a relative freedom of worship and speech. Hence, if the colonies remained through to the $21^{\text {st }}$ century, African ecclesiology and the quests for cultural continuity in general would have been crushed.

\section{Conclusion}

The article begun by attempting to understand the meaning and application of the concept of 'radical continuity' that Kibicho propounded to demonstrate that since the world has only one God, the God whom the indigenous Africans worshipped was one and the same God of the European missionaries. In addition, although some African elders felt that their religion needs to be taken radically without the Western and/or the Christian perspective of understanding God, God's nature remains. The article has cited CCM Kagumo to demonstrate the continuity of indigenous

35 FL Cross, 'Donatism', The Oxford dictionary of the Christian Church (New York: Oxford University Press, 2005).

36 FL Cross, 'Donatism', The Oxford dictionary of the Christian Church. 
rituals in African ecclesiology. The role of Ethaga-Irungu ritualists in handing over their Shrine to the church is a clear demonstration of continuity rather than a radical break. Even though there were cases where African Christianity (where African rituals dialogue with Christian rituals) was openly suppressed by the colonial forces, as in the case of the Donatists in North Africa, the surrender of sacred places by the local indigenous priests, without coercion, demonstrated continuity of indigenous rituals into and through African ecclesiology. Further, the use of the former sacred places where circumcision rituals took place, by the Afro-Pentecostals, as the new worship centres where baptism by immersion is now conducted in the $21^{\text {st }}$ century is another measurable pointer that there is continuity rather than a radical break from African indigenous rituals to the new religion. Likewise, the Mau-Mau rebels in the Kenya's quest for political independence demonstrated radical continuity of African religion through to African ecclesiology as their leader did not cut ties with the Roman Catholic Church despite his militant movement insisting on African rituals. It is therefore clear that enculturated Christianity will see the light of day in the $21^{\text {st }}$ century Africa unlike Donatism Christianity in North Africa that was phased out in early Christianity.

\section{Bibliography}

Barnett, DL \& Njama, K 1966. Mau-Mau From Within: Autobiography and analysis of Kenya's Peasant Revolt. London: Monthly Review Press.

Cross, FL 2005. 'Donatism', The Oxford dictionary of the Christian Church. New York: Oxford University Press.

Gathogo, Julius 2016. Mau-Mau Rebels in Kirinyaga County, Kenya. Saabrucken: Lambert Academic Publishers.

Gathogo, Julius 2014. Mau-Mau War and the Church in Kirinyaga, Kenya: Accounting for the Tension and Conflict (1952-1960), Studia Historiae Ecclesiasticae, December 2014, 40 (2): 19-41.

Gathogo, Julius 2011. Pangs of birth in African Christianity. Saarbrucken: Lambert Academic Publishers. 
Gitau, Samson K 2000. The Environmental Crisis: A Challenge for African Christianity. Nairobi: Acton.

Kibicho, SG 1972. The Kikuyu Conception of God, Unpublished PhD Thesis, Vanderbilt University, Tennessee, USA.

Kibicho, S 1981. 'The Teaching of African Religion in our Schools and Colleges and the Christian Attitude towards this Religion,' African Theological Journal 10 (1981) 3, 166-177.

Kibicho, SG 1978. 'The Continuity of the African Conception of God into and through Christianity: A Kikuyu Case-study.' In E. Fashole-Luke et al. (eds) 1978. Christianity in independent Africa (Bloomington and London: Indiana University Press).

Kibicho, SG 2006. God and Revelation. Nairobi: Acton.

Leakey, LSB 1954. Defeating Mau-Mau. London: Methuen.

Mwangi, R 1970. Kikuyu Folktales. Nairobi: East African Literature Bureau.

Ward, Kevin 1995. 'A History of Christianity in Uganda.' In From Mission to Church: A Handbook of Christianity in East Africa. Zablon Nthamburi (ed). Nairobi: Uzima. 33-46,

\section{Interviews}

Alice Wakanugu Ngaire at her Kabaro-Mutira home (25.03.13).

Beatrice Kagure-Naftaly Kinyua at her Kiamugo home (25.03.13).

Eunice Muthoni-Jeremiah Murimiat her Kirunda-Rubari home (, 25.03.13).

Irene Mumbi-Jeremiah Murimi at her Kirunda-Rubari home (25.03.13).

Jane Wanjiku Mwangi-Philip Mwangi Gaite at her Kagumo Trading house (25.03.13).

Priscilla Mbogo-Mbogo Kaara at her Mbiri-Mutira home (25.03.15).

Prof. Jesse Mugambi in his Nairobi West home (18.09.2016). 
John Kinyua Mwangi Gatimu at Kagumo Town home (13.04.2016). Aram Murage Hezekiah at Kagumo Town home (13.04.2016).

Joseph Karimi Karuri at Kagumo home (13.04.2016).

Rev. John Kangangi Mithamo at CCS Kerugoya Hotel (12.04.2016).

Julius Gicobi Ngure at CCS Kerugoya hotel (12.04.2016).

Joseph Kariuki Gatimu at Aberdare Annex Hotel, Mombasa, OffNkrumah Road (12.07.16). 